\title{
Acute mechanical complications in patients suffering from acute myocardial infarction
}

\author{
Francesco Formica', Serena Mariani ${ }^{2}$, Stefano D’Alessandro ${ }^{3}$ \\ 'Department of Medicine and Surgery, University of Milano-Bicocca, San Gerardo Hospital, Monza 20900, Italy. \\ ${ }^{2}$ Cardiac Surgery Unit, HagaZiekenhuis, Den Haag 2545 CH, The Netherlands. \\ ${ }^{3}$ Cardiac Surgery Unit, Cardio-Vascular-Thoracic Department, San Gerardo Hospital, Monza 20900, Italy.
}

\begin{abstract}
Correspondence to: Prof. Francesco Formica, Department of Medicine and Surgery, University of Milano-Bicocca, San Gerardo Hospital, Via Cadore 48, Monza 20900, Italy. E-mail: francesco_formica@fastwebnet.it; francesco.formica@unimib.it
\end{abstract}

\begin{abstract}
How to cite this article: Formica F, Mariani S, D'Alessandro S. Acute mechanical complications in patients suffering from acute myocardial infarction. Vessel P/us 2019;3:37. http://dx.doi.org/10.20517/2574-1209.2019.19
\end{abstract}

Received: 14 Jun 2019 First Decision: 21 Aug 2019 Revised: 17 Sep 2019 Accepted: 27 Sep 2019 Published: 18 Nov 2019

Science Editor: Mario F. L. Gaudino Copy Editor: Jing-Wen Zhang Production Editor: Jing Yu

\begin{abstract}
Acute mechanical complications following acute myocardial infarction have an incidence less the $1 \%$ in the era post coronary and systemic thrombolysis. However, the early mortality is still high even after surgical therapy, reaching $70 \%$. Left ventricle free wall rupture, ventricular septal defect and papillary muscle rupture represent the most challenging complications after myocardial infarction. Prompt diagnosis, appropriate medical therapy and mechanical support, such as intra-aortic balloon pump and extracorporeal membrane oxygenation, and urgent or emergency surgical operation may favor to obtain encouraging results and acceptable long-term outcome.
\end{abstract}

Keywords: Acute myocardial infarction, cardiac rupture, acute mitral valve regurgitation, left ventricular free wall rupture, ventricular septal defect

\section{INTRODUCTION}

Mechanical complications of myocardial infarction are direct consequences of anatomic and pathological changes occurring in ischemic cardiac tissue. After a coronary occlusion, there is a lack in blood perfusion and in oxygen supply that cause functional, morphological and biochemical changes. Within the first $30 \mathrm{~min}$ from the occlusion, reversible changes happen: macroscopic and microscopic changes are not occurring yet, but myofibrils start to relax, and cells start to suffer. After $30 \mathrm{~min}$, ischemic necrosis begins, and the irreversible damage occurs. After 2-4 h, complete necrosis of myocardial cells may occur,

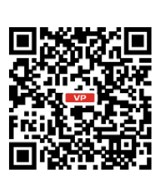


depending on the coronary collateral circulation, the severity and the time of coronary vessel occlusion and the individual demand for oxygen and nutrients. Loss of myocardial vitality is complete after $6-12 \mathrm{~h}$ from the onset of coronary occlusion. Within one week, macrophagic phagocytosis and irreversible collagen damage begin, and tissue becomes less resistant; in that period, myocardial tissue becomes more vulnerable and weaker and heart ruptures are more frequent ${ }^{[1,2]}$.

For the purpose of this review we analysed one of the 5 categories of complications of acute myocardial infarction (AMI) named as mechanical complications after AMI, such as ventricular free wall rupture, ventricular septal defect, papillary muscle rupture of mitral valve. The other 4 categories (electrical complication, inflammatory, ischemic and embolic complication) were exclude from this article.

Most of all mechanical complications of myocardial infarction require an urgent/emergent surgical therapy. Meanwhile, initial diagnosis should be rapid and initial medical therapy should be promptly started, to improve coronary perfusion, stabilise the haemodynamic condition and ameliorate the peripheral perfusion. Supplement oxygen, mechanical ventilatory support whether necessary, analgesic therapy, crystalloid infusion and inotropic agents represent usually the first medical approach. In very critical and challenging poor clinical and hemodynamic status, requirement of an intra-aortic balloon pump (IABP) or even a more advanced temporary circulatory support such as veno-arterial extracorporeal membrane oxygenation are valid option to manage and stabilise the patient $t^{[3]}$.

\section{LEFT VENTRICULAR FREE WALL RUPTURE}

Left ventricular free wall rupture (LVFWR) is account for 15\% after AMI and it is more frequent than septal or papillary muscle rupture ${ }^{[4,5]}$. LVFWR may occur at any time after myocardial infarction, usually within the first 3-5 days but may happen up two 15 days ${ }^{[6]}$. However, at least $25 \%$ of heart rupture occurs within the first $24 \mathrm{~h}$. The short-term mortality remains very high even rapid diagnosis and surgery. Data from one of the largest multicentre trial, the Global Registry of Acute Coronary Events study, report an incidence of LVFWR of $0.2 \%$ with an in-hospital mortality of $80 \%{ }^{[7]}$. In more recent retrospective studies and reviews, the early mortality was ranging between $14 \%$ to $35 \%$, according the initial haemodynamic status, the type of LVFWR and the type of surgical repair ${ }^{[3,8-10]}$.

Three types of cardiac rupture of cardiac rupture were classified as follows: acute, subacute, and chronic ${ }^{[11]}$. The acute rupture (also named "blow-out" rupture) is characterized by a massive haemopericardium [Figure 1] and most of patients presented with electro-mechanical dissociation and sudden cardiac death. When the rupture area is smaller, the bleeding is stopped by clot formation or pericardial adhesions. This type is called also "oozing" rupture, and patients presented with hypotension and arrhythmias and clinical signs of pericardial tamponade.

The accuracy of diagnosis of subacute LVFWR requires a high degree of suspicion ${ }^{[12]}$. Trans-thoracic echocardiogram is the first diagnostic tool as most of patients show pericardial effusion in addition to echogenic images, in an early period after AMI. Due to these findings, echocardiogram has a high level of sensitivity and specificity (more than 95\%) for the LVFWR diagnosis ${ }^{[13]}$. Furthermore, when pericardial effusion is more than $10 \mathrm{~mm}$ in patients with a recent diagnosis of AMI with ST elevation, the probability of 30 -day mortality is as high as $43 \%{ }^{[14]}$. When pericardial effusion is associated with hypotension and bradycardia, rapid pericardiocentesis is useful to stabilize the patients before taking the patients for emergency surgical therapy.

Surgical repair of the rupture site is the gold and definitive treatment. Surgery may be performed in different ways and different techniques according to the hemodynamic status and the types of cardiac rupture. In a recent review, Matteucci et al. ${ }^{[10]}$ described the following surgical techniques: (1) linear closure 


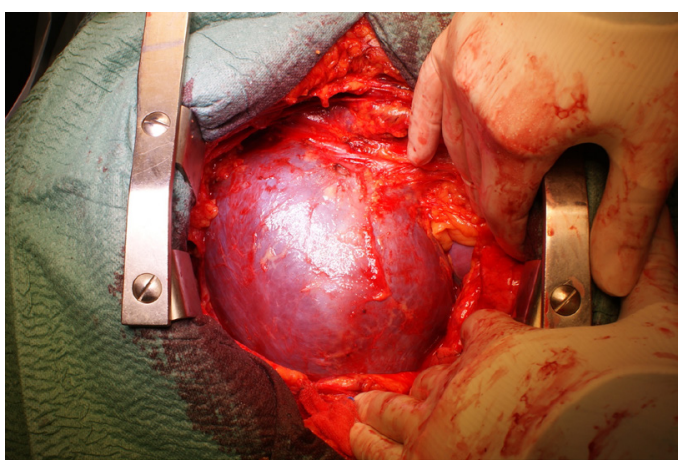

Figure 1. Massive hemopericardium following "blow-out" left ventricular free wall rupture

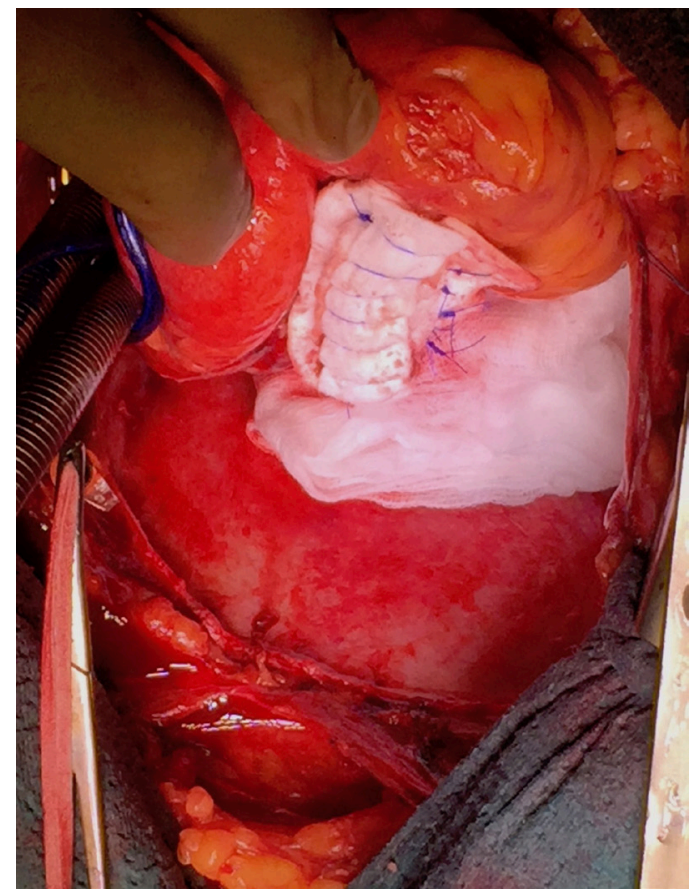

Figure 2. Linear closure of a "blow-out" left ventricular free wall rupture (inferior wall)

[Figure 2] or infartectomy associated to closure of the defect with a prosthetic patch when the LVFWR is a blow-out type ${ }^{[3]}$; (2) covering patch technique or sutureless technique (named also "patch and glue") in case of oozing LVFWR [Figure 3] $]^{[3,8]}$. Operations can be performed with or without cardiopulmonary bypass. Off-pump procedure is the technique of choice in case of oozing LVFWR and patients in stable conditions. Some authors heave recently reported newer surgical strategies, usually performed in presence of oozing by using different materials such as ready-to-use haemostatic collagen sponges ${ }^{[3,8,15]}$ and newer acellular xenogeneic extracellular matrix patches [Figure 4$]^{[16]}$.

Preoperative and postoperative insertion of IABP is advocated by some authors even when patients presented in stable haemodynamic status, with the aim to reduce the oxygen demand, the left ventricle wall tension and the left ventricle afterload ${ }^{[17,18]}$. This approach may reduce the risk of re-rupture during the early postoperative period. In the last 20 years, ECMO has emerged as a rescue tool to warrant a rapid haemodynamic stability in such patients presented with acute cardiogenic shock or even cardiac arrest ${ }^{[19,20]}$. ECMO may be use also to stabilize patients affected by LVFWR in referring hospitals ${ }^{[21,22]}$. However, there is 


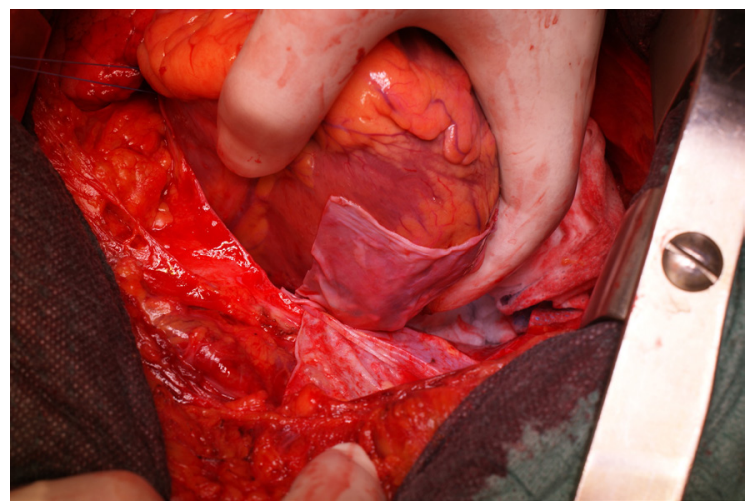

Figure 3. Sutureless techinique with autologous pericardial patch in "oozing" left ventricual free wall rupture

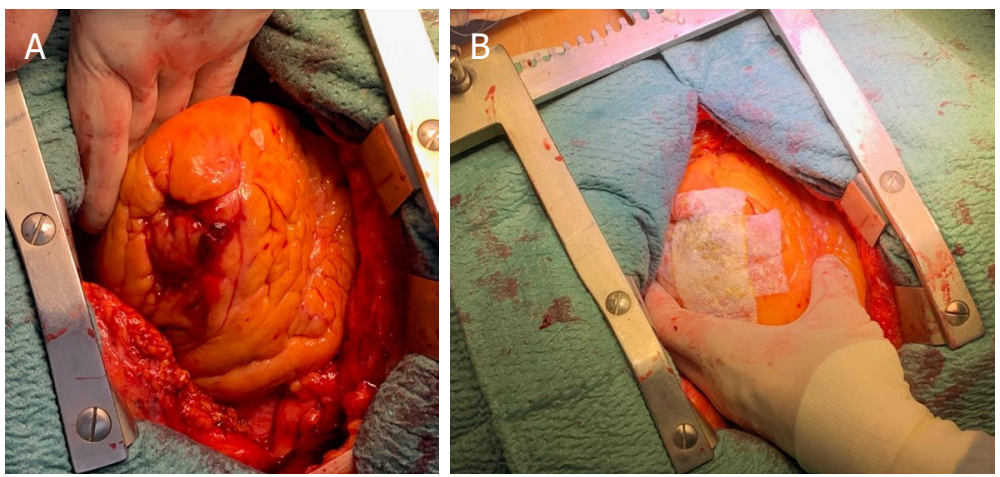

Figure 4. Oozing anterior left ventricular free wall rupture (A); ready-to-use haemostatic collagen sponges (B)

Table 1. Early and long-term outcome of left ventricular free wall rupture

\begin{tabular}{|c|c|c|c|}
\hline Authors & Patients & In-hospital mortality & Long-term survival \\
\hline Okamura et al. ${ }^{[8]}$ & 42 & $6(17 \%)$ & $\begin{array}{l}5 \text {-year: } 68.6 \% ; \\
10 \text {-year: } 62.9 \%\end{array}$ \\
\hline Formica et al. ${ }^{[3]}$ & 35 & $12(34.3 \%)$ & $\begin{array}{l}5 \text {-year: } 80.9 \% \\
10 \text {-year: } 74.7 \%\end{array}$ \\
\hline Sakaguchi et al. ${ }^{[23]}$ & 32 & $5(15.6 \%)$ & 5-year: $74 \%$ \\
\hline Zoffoli et al ${ }^{[24]}$ & 25 & $3(12 \%)$ & - \\
\hline McMullan et al. ${ }^{[25]}$ & 18 & $11(61 \%)$ & - \\
\hline
\end{tabular}

a lack of evidence of any benefit of preoperative and perioperative ECMO in patients affected from LVFWR due to the very low numbers of reports regarding this specific topic.

In-hospital mortality is extremely variable, ranging from $12 \%$ to $61 \%$ among different Institutions ${ }^{[3,8,23-25]}$. Despite the relative high in-hospital mortality, midterm and long term survival show encouraging outcome [Table 1].

\section{VENTRICULAR SEPTAL DEFECT}

The incidence of VSD has been estimated between $1 \%$ and $2 \%$ of all patients suffering from acute myocardial infarctions even if the advent of reperfusion therapy has decreased this value below $0.5 \%$. Despite the low incidence, the early mortality is still high, reaching about $60 \%-70 \%$. Without surgical treatment, only about $10 \%$ of patients survives after 3 months ${ }^{[26]}$. 
Risk factors for VSD include advanced age, hypertension, absence of angina, extensive myocardial infarction and single vessel disease ${ }^{[27,28]}$.

The acute rupture occurs 3-7 days after a wide transmural infarction but may occur rarely after 2 weeks ${ }^{[28,29]}$. VSD results in a left-to-right shunt which is the main cause of low cardiac output, decreased urine output, shortness of breath, altered mental status and finally cardiogenic shock ${ }^{[30]}$. At physical examination, a harsh and loud pan-systolic murmur at the left lower sternal border is present in over $90 \%$ of cases. A palpable thrill can be detected in up to $50 \%$ of patients.

VSDs has been categorized in two other categories: simple and complex. Simple rupture is a discrete lesion, with defect located at a similar level in both ventricles. That is typical pattern of anterior myocardial infarction. Inferior myocardial infarction usually is associate to a complex type ${ }^{[31,32]}$.

In both cases, the defect may vary in size from some $\mathrm{mm}$ to more than $15 \mathrm{~mm}$. The size of defect may affect the magnitude of left-to-right shunting, and therefore influencing the clinical presentation and the likelihood of survival. Trans-thoracic and transesophageal echocardiography with Doppler imaging is considered a high sensitive and specific diagnostic tool for immediate diagnosis.

Medical therapy is usually managed with the use of vasodilators, which reduce afterload and decrease left ventricular pressure and the left to right shunt, with inotropic agents, which may increase the cardiac output, diuretics, and IABP. Use of preoperative ECMO was reported in patients with refractory cardiogenic shock ${ }^{[3,34]}$. Some authors have reported the use of the Impella to achieve haemodynamic stabilization with acceptable results. However, the use of Impella is limited in selected patients and only few experiences with few patients were published so ar $^{[35-37]}$.

Timing of surgery is still debating. Recently, Papalexopoulou and co-workers published a review reporting that early surgery is advocated if VSD size is more than $15 \mathrm{~mm}$ and an instable haemodynamic. While delayed surgery might be performed up to 3 or 4 weeks in case of clear hemodynamic clinical status. Emergency surgery should be performed in patients with refractory cardiogenic shock and rapid deterioration $^{[38]}$. A review form the Society of Thoracic Surgeon National Database identifies that mortality of patients who underwent surgery within 7 days was approaching to $54 \%$ compared to patients who underwent surgery after 7 days. In this latter clinical scenario, mortality was $18 \%{ }^{[39]}$. Early mortality is affected also from the VSD location. In patients with basal or inferior VSD mortality is as high as $70 \%{ }^{[34]}$. Apical or anterior VSD are affected from a lower early mortality $(30 \%)^{[27]}$.

Right ventricular dysfunction is an issue to be considered in VSD. The right ventricular dysfunction maybe consequence of right ventricular infarction and right ventricle acute overload depending on the magnificence of the left-to-right shunt.

Multiple surgical techniques have been described [Figure 5]. Apical amputation is the simpler in patients with apical defects. Other techniques involve infarct exclusion and defect closure with a patch (biological or synthetic) using both stitches or glues ${ }^{[40,41]}$. Despite continuous advances in surgical approaches, operative mortality remains high (ranging from $20 \%$ to $71.4 \%$ ), with no clear differences between different techniques ${ }^{[41-43]}$. Female gender and depressed left ventricular dysfunction at admission are linked with a high hospital death ${ }^{[43]}$.

Table 2 reports the in-hospital mortality rates and long-term survival percentages of studies with relatively large number of patients. 

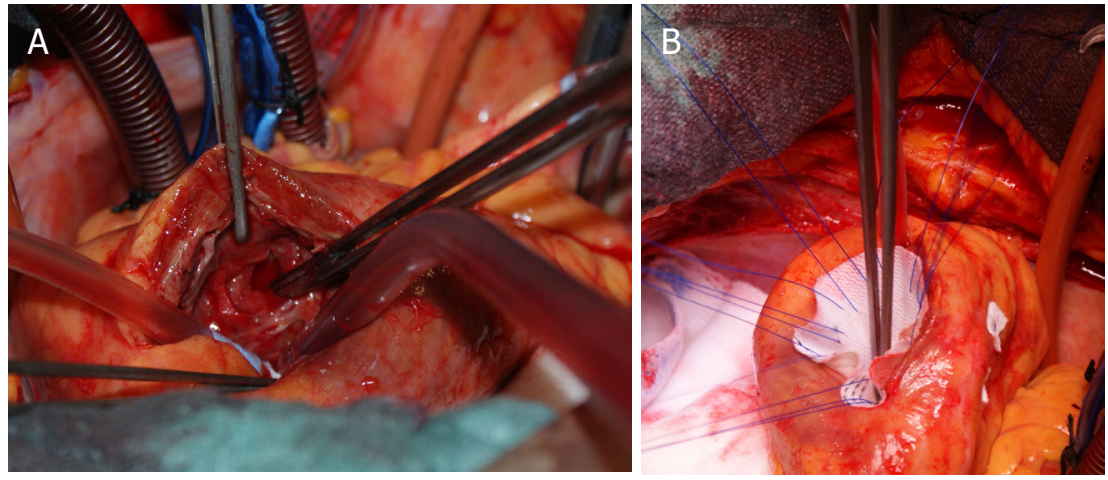

Figure 5. Apical ventricular septal defect (A); prosthetic patch for septal defect closure (B)

Table 2. Early and long-term outcome of ventricular septal defect

\begin{tabular}{|c|c|c|c|}
\hline Authors & Patients & In-hospital mortality & Long-term survival \\
\hline Pojar et al. ${ }^{[44]}$ & 39 & $14(36 \%)$ & - \\
\hline Okamoto et al. ${ }^{[45]}$ & 21 & $5(23.8 \%)$ & $\begin{array}{l}\text { 3-year: } 70.8 \% \\
8 \text {-year: } 57.9 \%\end{array}$ \\
\hline Liebelt et al. ${ }^{[42]}$ & 14 & $10(71.4 \%)$ & - \\
\hline Takahashi et al. ${ }^{[46]}$ & 52 & $19(36 \%)$ & $\begin{array}{l}5 \text {-year: } 75 \% \text {; } \\
\text { 10-year: } 31 \%\end{array}$ \\
\hline Papadopoulos et al..$^{[47]}$ & 32 & $10(31.2 \%)$ & $\begin{array}{l}5 \text {-year: } 79 \% ; \\
10 \text {-year: } 51 \%\end{array}$ \\
\hline Prêtre et $a{ }^{[48]}$ & 54 & $14(26 \%)$ & $\begin{array}{l}5 \text {-year: } 65 \% \\
10 \text {-year: } 40 \%\end{array}$ \\
\hline
\end{tabular}

Percutaneous closure of the VSD remains an attractive alternative to surgical repair mainly in extremely high-risks patients with reasonable results. Despite the in-hospital mortality is graved from a relatively high incidence (from $20 \%$ up to $46 \%$ ), the patients who survived to discharged had a very acceptable longterm survival ${ }^{[43,49]}$.

\section{PAPILLARY MUSCLE RUPTURE OF MITRAL VALVE}

Papillary muscle rupture (PMR) is a rare entity and occurs in less than $0.5 \%$ of patients with acute myocardial infarction ${ }^{[50]}$. Timing of rupture is ranging between 2 and 7 days, but $80 \%$ occurs in 7 days.

Mortality may be as high as $50 \%$ in the first $24 \mathrm{~h}$, and rises up to $90 \%$ within the first week ${ }^{[51]}$.

Anterior papillary muscles receive a dual blood coronary supply, while posterior papillary muscle receives blood from the only right coronary artery. Due to this anatomical difference, PMR is most common after an inferior acute myocardial infarction, because the posteromedial papillary muscle is most often involved.

Doppler transthoracic and transesophageal echocardiography is the gold diagnostic tool. Transesophageal echocardiography has a very high diagnostic accuracy approaching to $100 \%{ }^{[52]}$ for the evidence of a tear in papillary tissue and the flail of mitral valve leaflet leading to severe mitral regurgitation [Figure 6].

Emergent or urgent surgery is the only therapy for PMR, despite operative mortality rises up to $20 \%-39 \%{ }^{[33-55]}$. Medical therapy before surgery aims to reach a hemodynamic stability and includes aggressive afterload reduction to decrease the huge regurgitant fraction by using nitrates, sodium nitroprusside, diuretics, IABP. The use of ECMO was also reported. 


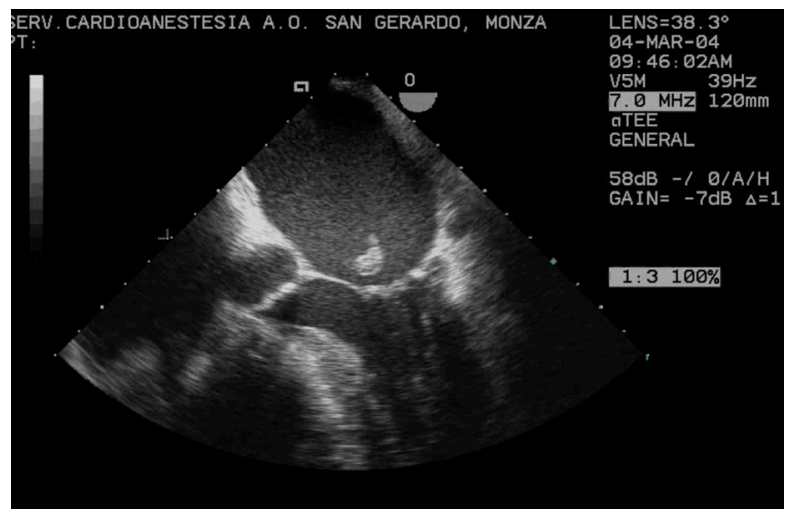

Figure 6. Transesophageal echocardiographic evidence of papillary muscle rupture
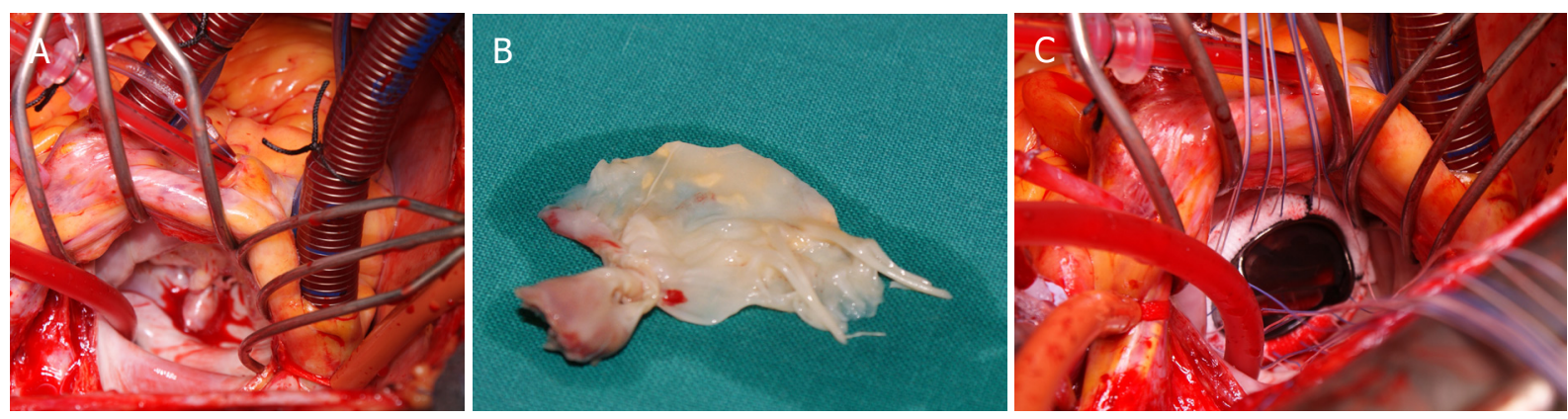

Figure 7. Surgical view of papillary position (A); posterior mitral leaflet and portion of papillary muscle (B); bi-leaflet prosthetic mechanical valve in mitral position (C)

Table 3. Early and long-term outcome of papillary muscle rupture

\begin{tabular}{|c|c|c|c|}
\hline Authors & Patients & In-hospital mortality & Long-term survival \\
\hline Bouma et $a l^{[54]}$ & 48 & $2(4.2 \%)$ & - \\
\hline Schroeter et al. ${ }^{[55]}$ & 28 & $11(39.3 \%)$ & - \\
\hline Tavakoli et al. ${ }^{[56]}$ & 21 & $4(19 \%)$ & $\begin{array}{l}5 \text {-year: } 68 \% \\
10 \text {-year: } 56 \%\end{array}$ \\
\hline Russo et al. ${ }^{[57]}$ & 54 & $10(18.5 \%)$ & $\begin{array}{l}5 \text {-year: } 79 \% \\
10 \text {-year: } 55 \%\end{array}$ \\
\hline
\end{tabular}

Surgical technique depends upon the location and the type of rupture. In case of partial PMR, surgeons usually attempt for a repair of mitral valve. However, a surgical repair of the papillary muscle head is really rare. In case of complete PMR, mitral valve replacement becomes the treatment of choice Figure $7^{[53,54]}$.

Long-term survival of patients who underwent mitral valve replacement for PMR is very acceptable, with a 5-year survival rate ranging between $60 \%-70 \%{ }^{[6,57]}$.

Table 3 reports the in-hospital mortality rates and long-term survival percentages of studies with relatively large number of patients.

\section{CONCLUSION}

Mechanical complications after acute myocardial infarction are still affected by high 30-day mortality and poor long-term survival. The incidence of such complications is reduced in the post thrombolysis era, but the perioperative surgery continues to be relatively high. The diagnosis should be as prompt as possible, 
since in case of acute cardiogenic shock the surgery should be performed very early to increase the perioperative survival. Rescue tool as ECMO is an emerged therapy to stabile patients and even allowing the stabilization in referring hospital.

\section{DECLARATIONS}

\section{Authors' contributions}

Made substantial contributions to conception and design of the study and performed literature search and interpretation: Formica F, Mariani S, D’Alessandro S

\section{Availability of data and materials}

Not applicable.

\section{Financial support and sponsorship}

None.

\section{Conflicts of interest}

All authors declared that there are no conflicts of interest.

\section{Ethical approval and consent to participate}

Not applicable.

\section{Consent for publication}

Not applicable.

\section{Copyright}

(c) The Author(s) 2019.

\section{REFERENCES}

1. Thygesen K, Alpert JS, Jaffe AS, Simoons ML, Chaitman BR, et al; Writing Group on behalf of the Joint ESC/ACCF/AHA/WHF Task Force for the Universal Definition of Myocardial Infarction. Third universal definition of myocardial infarction. Glob Heart 2012;7:275-95.

2. Marques JS, Jorge C, Feija A, Diogo AN. Acute myocardial infarction complication diagnosed by three-dimensional echocardiography. Eur J Echocardiogr 2011;12:E29.

3. Formica F, Mariani S, Singh G, D’Alessandro S, Messina LA, et al. Postinfarction left ventricular free wall rupture: a 17-year singlecentre experience. Eur J Cardiothorac Surg 2018;53:150-6.

4. Becker RC, Gore JM, Lambrew C, Weaver WD, Rubison RM, et al. A composite view of cardiac rupture in the United States National Registry of Myocardial Infarction. J Am Coll Cardiol 1996;27:1321-6.

5. Becker RC, Hochman JS, Cannon CP, Spencer FA, Ball SP, et al. Fatal cardiac rupture among patients treated with thrombolytic agents and adjunctive thrombin antagonists: observations from the thrombolysis and thrombin inhibition in myocardial infarction 9 study. J Am Coll Cardiol 1999;33:479-87.

6. Figueras J, Cortadellas J, Soler-Soler J. Left ventricular free wall rupture: clinical presentation and management. Heart 2000;83:499504.

7. López-Sendón J, Gurfinkel EP, Lopez de Sa E, Agnelli G, Gore JM, et al; Global registry of acute coronary events (GRACE) investigators. Factors related to heart rupture in acute coronary syndrome in the global registry of coronary eventes. Eur Heart $\mathrm{J}$ 2010;31:1449-56.

8. Okamura H, Kimura N, Mieno M, Matsumoto H, Yuri K, et al. Sutureless repair for postinfarction left ventricular free wall rupture. J Thorac Cardiovasc Surg 2019;158:771-7.

9. Matteucci M, Fina D, Jiritano F, Blankesteijn WM, Raffa GM, et al. Sutured and sutureless repair of postinfarction left ventricular free-wall rupture: a systematic review. Eur J Cardiothorac Surg 2019;56:840-8.

10. Matteucci M, Fina D, Jiritano F, Meani P, Blankesteijn WM, et al. Treatment strategies for post-infarction left ventricula rupture. Eur Heart J Acute Cardiovasc Care 2019;8:379-87.

11. Becker AE, van Mantgem JP. Cardiac tamponade: a study of 50 hearts. Eur J Cardiol 1975;3:349-58.

12. López-Sendón J, González A, López de Sá E, Coma-Canella I, Roldán I, et al. Diagnosis of subacute ventricular wall rupture after 
acute myocardial infarction: sensitivity and specificity of clinical, hemodynamic and echocardiographic criteria. J Am Coll Cardiol 1992;19:1145-53.

13. Galve E, Garcia-Del-Castillo H, Evangelista A, Batlle J, Permanyer-Miralda G, et al. Pericardial effusion in the course of myocardial infarction: incidence, natural history, and clinical relevance. Circulation 1986;73:294-9.

14. Figueras J, Barrabés JA, Serra V, Cortadellas J, Lidón RM, et al. Hospital outcome of moderate to severe pericardial effusion complicating ST-elevation acute myocardial infarction. Circulation 2010;122:1902-9.

15. Fujimatsu T, Oosawa H, Takai F, Aruga M, Ogiwara F, et al. Patch-and-glue sutureless repair for blowout rupture after myocardial infarction: report of two cases. Ann Thorac Cardiovasc Surg 2008;14:48-51.

16. Holubec T, Caliskan E, Bettex D, Maisano F. Repair of post-infarction left ventricular free wall rupture using an extracellular matrix patch. Eur J Cardiothorac Surg 2015;48:800-3.

17. Zeebregts CJ, Noyez L, Hensens AG, Skotnicki SH, Lacquet LK. Surgical repair of subacute left ventricular free wall rupture. J Card Surg 1997;12:416-9.

18. Okada K, Yamashita T, Matsumori M, Hino Y, Hanafusa Y, et al. Surgical treatment for rupture of left ventricular free wall after acute myocardial infarction. Interact Cardiovasc Thorac Surg 2005;4:203-6.

19. Formica F, Corti F, Avalli L, Paolini G. ECMO support for the treatment of cardiogenic shock due to left ventricular free wall rupture. Interact Cardiovasc Thorac Surg 2005;4:30-2.

20. Avalli L, Maggioni E, Formica F, Redaelli G, Migliari M, et al. Favourable survival of in-hospital compared to out-of-hospital refractory cardiac arrest patients treated with extracorporeal membrane oxygenation: an Italian tertiary care centre experience. Resuscitation 2012;83:579-83.

21. Formica F, Avalli L, Redaelli G, Paolini G. Interhospital stabilization of adult patients with refractory cardiogenic shock by venoarterial extracorporeal membrane oxygenation. Int J Cardiol 2011;147:164-5.

22. Beurtheret S, Mordant P, Paoletti X, Marijon E, Celermajer DS, et al. Emergency circulatory support in refractory cardiogenic shock patients in remote institutions: a pilot study (the cardiac-RESCUE program). Eur Heart J 2013;34:112-20.

23. Sakaguchi G, Komiya T, Tamura N, Kobayashi T. Surgical treatment for postinfarction left ventricular free wall rupture. Ann Thorac Surg 2008;85:1344-6.

24. Zoffoli G, Battaglia F, Venturini A, Asta A, Terrini A, et al. A novel approach to ventricular rupture: clinical needs and surgical technique. Ann Thorac Surg 2012;93:1002-3.

25. McMullan MH, Maples MD, Kilgore TL Jr, Hindman SH. Surgical experience with left ventricular free wall rupture. Ann Thorac Surg 2001;71:1894-8.

26. Deja MA, Szostek J, Widenka K, Szafron B, Spyt TJ, et al. Post infarction ventricular septal defect - can we do better? Eur J Cardiothorac Surg 2000;18:194-201.

27. Menon V, White H, LeJemtel T, Webb JG, Sleeper LA, et al. The clinical profile of patients with suspected cardiogenic shock due to predominant left ventricular failure: a report from the SHOCK trial registry. Should we emergently revascularize occluded coronaries in cardiogenic shock? J Am Coll Cardiol 2000;36:1071-6.

28. Crenshaw BS, Granger CB, Birnbaum Y, Pieper KS, Morris DC, et al. Risk factors, angiographic patterns, and outcomes in patients with ventricular septal defect complicating acute myocardial infarction. GUSTO-I (Global Utilization of Streptokinase and TPA for Occluded Coronary Arteries) Trial Investigators. Circulation 2000;101:27-32.

29. Yip HK, Fang CY, Tsai KT, Chang HW, Yeh KH, et al. The potential impact of primary percutaneous coronary intervention on ventricular septal rupture complicating acute myocardial infarction. Chest 2004;125:1622-8.

30. Hayashi T, Hirano Y, Takai H, Kimura A, Taniguchi M, et al. Usefulness of ST-segment elevation in the inferior leads in predicting ventricular septal rupture in patients with anterior wall acute myocardial infarction. Am J Cardiol 2005;96:1037-41.

31. Lemery R, Smith HC, Giuliani ER, Gersh BJ. Prognosis in rupture of the ventricular septum after acute myocardial infarction and role of early surgical intervention. Am J Cardiol 1992;70:147-51.

32. Reynolds HR, Hochman JS. Heartbreak. Eur Heart J 2010;31:1433-5.

33. Formica F, Avalli L, Colagrande L, Ferro O, Greco G, et al. Extracorporeal membrane oxygenation to support adult patients with cardiac failure: predictive factors of 30-day mortality. Interact Cardiovasc Thorac Surg 2010;10:721-6.

34. Doll N, Kiaii B, Borger M, Bucerius J, Krämer K, et al. Five-year results of 219 consecutive patients treated with extracorporeal membrane oxygenation for refractory postoperative cardiogenic shock. Ann Thorac Surg 2004;77:151-7.

35. Ibebuogu UN, Bolorunduro O, Hwang I. Impella-assisted transcatheter closure of an acute postinfarction ventricular septal defect. BMJ Case Rep 2016;2016.

36. Peltan J, Oses P, Calderon J, Casassus F, Barandon L. Impella 5.0 microaxia pump as a right ventricular assist device after surgical treatment of posterior post-infarction ventricular septal defect. Perfusion 2014;29:472-6.

37. La Torre MW, Centofanti $\mathrm{P}$, Attisani M, Patanè F, Rinaldi M. Posterior ventricular septal defect in presence of cardiogenic shock: early implantation of the impella recover LP 5.0 as a bridge to surgery. Tex Heart Inst J 2011;38:42-9.

38. Papalexopoulou N, Young CP, Attia RQ. What is the best timing of surgery in patients with post-infarct ventricular septal rupture? Interact Cardiovasc Thorac Surg 2013;16:193-6.

39. Arnaoutakis GJ, Zhao Y, George TJ, Sciortino CM, McCarthy PM, et al. Surgical repair of ventricular septal defect after myocardial infarction: outcomes from the Society of Thoracic Surgeons National Database. Ann Thorac Surg 2012;94:436-43.

40. Cinq-Mars A, Voisine P, Dagenais F, Charbonneau É, Jacques F, et al. Risk factors of mortality after surgical correction of ventricular septal defect following myocardial infarction: retrospective analysis and review of the literature. Int J Cardiol 2016;206:27-36. 
41. Miyajima M, Kawashima T, Saito T, Yokoyama H, Ohori K, et al. Delayed closure of postinfarction ventricular septal rupture. Ann Thorac Cardiovasc Surg 2010;16:128-30.

42. Liebelt JJ, Yang Y, DeRose JJ, Taub CC. Ventricular septal rupture complicating acute myocardial infarction in the modern era with mechanical circulatory support: a single center observational study. Am J Cardiovasc Dis 2016;6:10-6.

43. Tai S, Tang JJ, Tang L, Ni YQ, Guo Y, et al. Management and outcome of ventricular septal rupture complicating acute myocardial infarction: what is new in the era of percutaneous intervention? Cardiology 2018;141:226-32.

44. Pojar M, Harrer J, Omran N, Turek Z, Striteska J, et al. Surgical treatment of postinfarction ventricular septal defect: risk factors and outcome analysis. Interact Cardiovasc Thorac Surg 2018;26:41-6.

45. Okamoto Y, Yamamoto K, Asami F, Kimura M, Mizumoto M, et al. Early and midterm outcomes of triple patch technique for postinfarction ventricular septal defects. J Thorac Cardiovasc Surg 2016;151:1711-6.

46. Takahashi H, Arif R, Almashhoor A, Ruhparwar A, Karck M, et al. Long-term results after surgical treatment of postinfarction ventricular septal rupture. Eur J Cardiothorac Surg 2015;47:720-4

47. Papadopoulos N, Moritz A, Dzemali O, Zierer A, Rouhollapour A, et al. Long-term results after surgical repair of postinfarction ventricular septal rupture by infarct exclusion technique. Ann Thorac Surg 2009;87:1421-5.

48. Prêtre R, Ye Q, Grünenfelder J, Lachat M, Vogt PR, et al. Operative results of "repair" of ventricular septal rupture after acute myocardial infraction. Am J Cardiol 1999;84:785-8.

49. Calvert PA, Cockburn J, Wynne D, Ludman P, Rana BS, et al. Percutaneous closure of postinfarction ventricular septal defect: inhospital outcomes and long-term follow-up of UK experience. Circulation 2014;129:2395-402.

50. French JK, Hellkamp AS, Armstrong PW, Cohen E, Kleiman NS, et al. Mechanical complications after percutaneous coronary intervention in ST-elevation myocardial infarction (from APEX-AMI). Am J Cardiol 2010;105:59-63.

51. Nishimura RA, Gersh BJ, Schaff HV. The case for an aggressive surgical approach to papillary muscle rupture following myocardial infarction: "From paradise lost to paradise regained". Heart 2000;83:611-3.

52. Enriquez-Sarano M, Freeman WK, Tribouilloy CM, Orszulak TA, Khandheria BK, et al. Functional anatomy of mitral regurgitation: accuracy and outcome implications of transesophageal echocardiography. J Am Coll Cardiol 1999;34:1129-36.

53. Bouma W, Wijdh-den Hamer IJ, Koene BM, Kuijpers M, Natour E, et al. Predictors of in-hospital mortality after mitral valve surgery for post-myocardial infarction papillary muscle rupture. J Cardiothorac Surg 2014;19:171.

54. Bouma W, Wijdh-den Hamer IJ, Klinkenberg TJ, Kuijpers M, Bijleveld A, et al. Mitral valve repair for post-myocardial infarction papillary muscle rupture. Eur J Cardiothorac Surg 2013;44:1063-9.

55. Schroeter T, Lehmann S, Misfeld M, Borger M, Subramanian S, et al. Clinical outcome after mitral valve surgery due to ischemic papillary muscle rupture. Ann Thorac Surg 2013;95:820-4.

56. Tavakoli R, Weber A, Vogt P, Brunner HP, Pretre R, et al. Surgical management of acute mitral valve regurgitation due to postinfarction papillary muscle rupture. J Heart Valve Dis 2002;11:20-5.

57. Russo A, Suri RM, Grigioni F, Roger VL, Oh JK, et al. Clinical outcome after surgical correction of mitral regurgitation due to papillary muscle rupture. Circulation 2008;118:1528-34. 